\title{
Natural selection on TMPRSS6 associated with the \\ blunted erythropoiesis and improved blood viscosity
}

\section{in Tibetan Pigs}

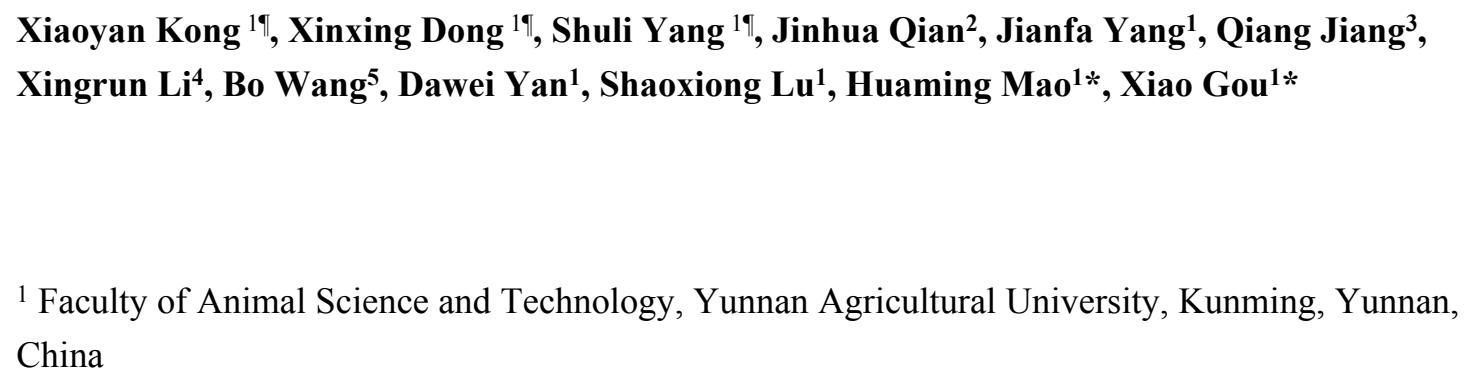

${ }^{1}$ Faculty of Animal Science and Technology, Yunnan Agricultural University, Kunming, Yunnan, China

${ }^{2}$ Department of Animal Science, Yuxi Agriculture Vocational-Technical College, Yuxi, Yunnan, China

${ }^{3}$ Dairy Cattle Research Center, Shandong Academy of Agricultural Science, Jinan, Shandong, China

${ }^{4}$ Department of Animal Science, Dali Vocational and Technical College of Agriculture and Forestry, Dali, Yunnan, China

${ }^{5}$ Research Experimental Center, Yunnan University of Traditional Chinese Medicine, Kunming, Yunnan, China

* Corresponding authors maohm@vip.sina.com (HMM); gouxiaosa@163.com (XG)

qThese authors contributed equally to this work. 


\section{Abstract}

Tibetan pigs, indigenous to Tibetan plateau, are well adapted to hypoxia. So far, there have been not any definitively described genes and functional sites responsible for hypoxia adaptation for the Tibetan pig. Here we conducted resequencing of the nearly entire genomic region $(40.1 \mathrm{~kb})$ of the candidate gene TMPRSS6 (Transmembrane protease, serine 6) associated with hemoglobin concentration (HGB) and red blood cell count (RBC) in 40 domestic pigs and 40 wild boars from five altitudes along the Tea-horse ancient road and identified 708 SNPs, in addition to an indel (CGTG/----) in the intron 10. Both the CGTG deletion frequency and the pairwise $\mathrm{r}^{2}$ linkage disequilibrium showed an increase with elevated altitudes in 838 domestic pigs from five altitudes, suggesting that TMPRSS6 has been under Darwinian positive selection. As the conserved core sequence of hypoxia-response elements (HREs), the deletion of CGTG in Tibetan pigs decreased the expression levels of TMPRSS6 mRNA and protein in the liver revealed by real-time quantitative PCR and western blot, respectively. To explore whether reduced TMPRSS6 expression level could improve blood viscosity, the relationship between CGTG indel and hematologic and hemorheologic parameters in 482 domestic pigs from continuous altitudes was detected and dissected a genetic effect on reducing $\mathrm{HGB}$ by $13.25 \mathrm{~g} / \mathrm{L}$ in Gongbo'gyamda Tibetan pigs and decreasing MCV by $4.79 \mathrm{fl}$ in Diqing Tibetan pigs. In conclusion, the CGTG deletion of TMPRSS6 resulted in lower HGB and smaller $\mathrm{MCV}$, thereby blunting erythropoiesis and improving blood viscosity as well as erythrocyte deformability. 
Keywords : Tibetan Pigs; TMPRSS6; HGB; CGTG indel; High-altitude adaptation

\section{Introduction}

The Tibetan pig lives at an average elevation of approximately $3500 \mathrm{~m}$ on Tibetan plateau [1], due to the availability of well-adapted extreme conditions including low ambient temperature, high ultraviolet radiation, harsh climate, and low oxygen [2]. For thousands of years, Tibetan pigs have developed complex phenotypic and physiological adaptations to high-altitude hypoxia compared with lowland pigs [3]. When animals are exposed to chronic hypoxia, the pulmonary artery pressure and red blood cell count (RBC) increase, causing pulmonary hypertension and right ventricular hypertrophy. Experimental evidence indicates that pulmonary artery pressure, pulmonary artery wedge pressure, cardiac output and pulmonary vascular resistance increase with increased elevations in pigs [4].

The hypoxia-induced increase in RBC and HGB, thereby rising blood viscosity and resistance, result in pulmonary hypertension and right-heart failure [5]. In the past few years, increasing attentions have been devoted to identify the genes related to blood physiology underlying the adaptation to high-altitude hypoxia for Tibetans [6-9], yaks [10,11], Tibetan chickens [12], Tibetan antelopes [13], pikas [14], Tibetan pigs $[2,3,15]$, and deer mice [16]. Multiple genome-wide scans showed that positive selection in human beings and animals at high altitude occurred mainly in the hypoxia-inducible factor (HIF) signaling pathway [3,6,17-24]. In this pathway, EPAS1 (endothelial PAS domain protein 1) and EGLN1 (egl nine homolog 1) are key genes that correlated significantly with hemoglobin concentration $[6,11,23,25-27]$. 
The genome-wide associated with blood physiology also revealed that the gene TMPRSS6 (Transmembrane protease, serine 6, one of the downstream genes in the HIF pathway) was strongly correlated with serum iron concentration $[28,29,38$ 43,30-37], RBC, and HGB [44-46]. This gene encodes a type II transmembrane serine proteinase (Matriptase 2) expressing in the liver [47], and regulates the iron metabolism by controlling the hepcidin expression $[33,35,37,39,48,49]$. A genome-wide meta-analysis also identifies TMPRSS6 associated with hematological parameters in the HaemGen consortium [46]. Current evidence allso suggests that the TMPRSS6 variants were significantly associated with plasma ferritin, hemoglobin, risk of iron overload, and type 2 diabetes in Chinese Hans [50]. Several lines of evidence, mutations in TMPRSS6 are known to be associated with cause iron-refractory iron deficiency anemia $[36,37,41,42,51,52]$ or iron deficiency[31,35,53-55], especially one mutation 736 (V) allele (rs855791) allele tended to be associated with low $\mathrm{Hb}$ levels and iron status in humans $[35,36,38,39,44,45,56]$.

In this study, we aim to probe into the potential role of the TMPRSS6 gene underlying blood physiological adaptation to high-altitude Tibetan pigs. Resequencing of the nearly complete genomic region of TMPRSS6 $(40.1 \mathrm{~kb})$ was conducted to explore the molecular mechanism of adaptation to high-altitude hypoxia in Tibetan pigs. Otherwise, real-time quantitative PCR and western blot were performed to determine the expression level of TMPRSS6. Meanwhile, hematologic and hemorheologic parameters were measured to analyze the association with 
TMPRSS6, including red blood cell count (RBC), hemoglobin concentration (HGB), hematocrit (HCT), mean corpuscular volume (MCV), mean corpuscular hemoglobin $(\mathrm{MCH})$, mean corpuscular hemoglobin concentration (MCHC) and red blood cell distribution width (RDW).

\section{Materials and methods}

\section{Ethics Statement}

All animal experimental procedures were performed according to the Guide for the

Care and Use of Laboratory Animals (Ministry of Science and Technology of China, 2006).

\section{Animal and sample preparation}

In this study, a total of 838 domestic pigs were included, in which 353 Tibetan pigs were from 5 different locations in Tibetan plateau and 485 pigs were from 9 domestic breeds across the other three altitudes along the Tea-horse ancient road, and 40 Chinese wild boars were sampled from 5 continuous altitudes along the Tea-horse ancient road. Sample size and localization of each population were shown in Supplementary Table S1 and Fig 1. 80 individuals including 40 domestic pigs and 40 Chinese wild boars were used for TMPRSS6 resequencing. 838 pigs were genotyped for haplotype analyze of TMPRSS6 gene. Hematologic and hemorheologic parameters (Table S2) of 482 pigs from the 838 domestic pigs were detected. Ten Gongbo'gyamda Tibetan pigs with genotype DD $(n=5)$ and II $(n=5)$ were selected to detect expression level of mRNA and protein by real-time quantitative PCR 
(RT-qPCR) and western-blot experiments. Liver tissue specimens were collected and immediately frozen in liquid nitrogen.

Fig 1. Sampling and geographic locations of the pig breeds. The red, yellow, green, blue and purple indicated high level of high altitude (HHA, 3600 meters), middle level of high altitude (MHA, 3300 meters), low level of high altitude (LHA, 2500 meters), middle level of altitude (MH, 1600 meters) and low level of altitude (LA, 550 meters), respectively. TT, Tibetan (Gongbo'gyamda); YNT, Tibetan (Yunnan); SCT, Tibetan (Sichuan); QHT, Tibetan (Qinghai); GST, Tibetan (Gansu); LJ, Lijiang; BS, Baoshan; SB, Saba; DN, Diannanxiaoer; TC, Tengchong; GL, HighLiGongshan.

\section{Resequencing, genotyping and haplotype analysis}

The TMPRSS6 gene (Genbank accession no. NC_010447) was resequenced in 40 domestic pigs and 40 wild boars across 5 continuous altitudes, 10 individuals per altitude. A sample of $5 \mathrm{~mL}$ blood from each individual pig was obtained from the jugular vein. Blood genomic DNA was extracted with a Genomic DNA Isolation Kit (Bactec, Beijing, China) according to the manufacturer's instructions. We designed 55 pairs of primers to amplify the entire gene, including 17 pairs of primers for exons and 38 pairs of primers for introns (Table S3). PCR was performed in $25 \mu \mathrm{L}$ reaction volume. The ingredient comprised $2 \mu \mathrm{L}$ DNA template, $11 \mu \mathrm{L}$ Mix, $1 \mu \mathrm{mol} / \mathrm{L}$ of each forward and reverse primer and $10 \mu \mathrm{L} \mathrm{ddH}_{2} \mathrm{O}$. PCR procedure was performed as following: initial denaturation for $5 \mathrm{~min}$ at $95{ }^{\circ} \mathrm{C}$, followed by 36 cycles of $95^{\circ} \mathrm{C}$ for $30 \mathrm{~s}$; annealing at prescribed annealing temperature (Table S3) for $30 \mathrm{~s}$; and extension at $72^{\circ} \mathrm{C}$ for $45 \mathrm{~s}$. The final extension was performed at $72^{\circ} \mathrm{C}$ for $8 \mathrm{~min}$. PCR products 
were sequenced using an ABI 3730 sequence analyzer (Applied Biosystems, Foster City, CA). TMPRSS6 SNPs were genotyped also by Sanger sequencing. The sequence polymorphisms were analyzed using MEGA7 software[57]. The LD map of TMPRSS6 SNPs in the domestic pigs and wild boars was constructed by Haploview using the $\mathrm{r}^{2}$ algorithm [58].

\section{Hematologic and Hemorheologic parameters}

Hematologic parameters were measured by BC-2800Vet Auto Hematology Analyzer (Mindray Co., Ltd.). The following measurements were obtained: red blood cell count (RBC), hemoglobin concentration (HGB), hematocrit (HCT), mean corpuscular volume (MCV), mean corpuscular hemoglobin $(\mathrm{MCH})$, mean corpuscular hemoglobin concentration (MCHC) and red blood cell distribution width (RDW), respectively. Hemorheologic parameters were measured using a ZL1000 Auto Blood Rheology Analyzer (Zonci Co., Ltd.) at a constant temperature of $37^{\circ} \mathrm{C}$. The following measurements were obtained: fibrinogen (FB), plasma viscosity (PV), whole blood relative index of low shear (WLS) at shear rate of $1 \mathrm{~S}^{-1}$, whole blood relative index of middle shear (WMS) at shear rate of $5 \mathrm{~S}^{-1}$, whole blood relative index of high shear (WHS) at shear rate of $200 \mathrm{~S}^{-1}$, RBC aggregation index (EAI), RBC aggregation coefficient (EAC), casson viscosity (CV), RBC internal viscosity (RBCIV), low shear flow resistance (LSFR) at shear rate of $1 \mathrm{~S}^{-1}$, middle shear flow resistance (MSFR) at shear rate of $5 \mathrm{~S}^{-1}$, high shear flow resistance (HSFR) at shear rate of $200 \mathrm{~S}^{-1}$, yield stress (YS) respectively. Parameters were measured immediately after veinpuncture. 


\section{Real-time quantitative PCR}

Total RNA was extracted from the livers with total RNA extraction kit(DP419) (Tiangen, Beijing, China). The concentration and purity of RNA were determined with a NanoDrop 2000 Biophotometer (Thermo Fisher Scientific Inc., West Palm Beach, FL, USA) and integrity was verified by electrophoresis in a $1 \%$ agarose gel. After treatment with DNase I, $2 \mu \mathrm{g}$ of RNA in a $20 \mu \mathrm{L}$ reaction volume was reversely transcribed into cDNA using a cDNA Kit (TaKaRa, Dali, China). To avoid genomic DNA contamination, Primer Premier 5.0 software was used to design TMPRSS6 gene (XM_001924749) primers that amplified products spanning an intron. The primers were 5'-CCCGATTCGCTCTTCTCC-3' and 5'- GGCACCTTCCTTTCA CCC-3'. The 28s rRNA (DQ297674) was used as the internal standard and its primers were 5'-CGGGATGAACCGAACGC-3' and 5'-GCCACCGTCCTGCTGTCT-3'. Real-time quantitative PCR (RT-qPCR) was conducted on the Bio-Rad CFX96 System (Bio-Rad, USA). Each reaction mixture contained $10.0 \mu \mathrm{L} 2 \times$ SYBR Green qPCR SuperMix (Transgen, Beijing, China), $1.0 \mu \mathrm{L}$ cDNA, $0.5 \mu \mathrm{L}$ of each primer (10.0 $\mathrm{nmol} / \mu \mathrm{L}$ ), $\mathrm{ddH}_{2} \mathrm{O}$ water was added to adjust the volume to $20.0 \mu \mathrm{L}$. The RT-qPCR program started with denaturation at $95{ }^{\circ} \mathrm{C}$ for 15 min followed by 39 cycles of denaturation at $95{ }^{\circ} \mathrm{C}$ for $10 \mathrm{~s}$ and annealing elongation at $63{ }^{\circ} \mathrm{C}$ for $30 \mathrm{~s}$, during which fluorescence was measured. Next, a melting curve was constructed by increasing the temperature from $65{ }^{\circ} \mathrm{C}$ to $95{ }^{\circ} \mathrm{C}$ in sequential steps of $0.5^{\circ} \mathrm{C}$ for $5 \mathrm{~s}$, during which fluorescence was measured. The RT-qPCR efficiency of each pair of primers was calculated using 5 points in a 5 -fold dilution series of cDNA, which was 
used to construct a standard curve. A cDNA pool of all samples was used as a calibration and three replications of each sample were performed. Gene expression levels were calculated using the $2^{-\Delta \Delta \mathrm{Ct}}$ method $(\Delta \Delta \mathrm{Ct}=\Delta \mathrm{Ct}$ target gene $-\Delta \mathrm{Ct}$ 28srRNA gene) as previously described [59].

\section{Western blot}

The liver tissue was homogenized using a Mixer MillMM400 (Retsch, Germany) for 5 min and then centrifuged at $10,000 \times \mathrm{g}$ for $10 \mathrm{~min}$ at $4{ }^{\circ} \mathrm{C}$. Protein concentrations were determined using a Protein Assay Kit (Bio-Rad). Proteins $(40 \mu \mathrm{g})$ were separated by sodium dodecyl sulfate polyacrylamide gel electrophoresis (SDS- PAGE) using a $5 \%$ stacking gel and a $10 \%$ separating gel. Following electrophoresis, proteins were transferred to Immobilon-P Transfer Membranes (IPVH00010) for $2 \mathrm{~h}$ at $300 \mathrm{~mA}$ using a Bio-Rad Criterion Blotter. Membranes were blocked overnight in blocking buffer (P0023B, Beyotime Ltd., China) and then incubated with primary mouse monoclonal GAPDH (1:1,000 dilution, AG019, Beyotime Ltd., China) and Anti-tmpss6 (n-terminal) polyclonal antibody (1:500 dilution, Sigma) diluted in primary antibody dilution buffer (P0023A, Beyotime Ltd., China) at $4{ }^{\circ} \mathrm{C}$ for $2 \mathrm{~h}$. The membranes were washed 3 times with PBST (phosphate buffer saline containing $0.1 \%$ Tween 20), and incubated with secondary goat anti-rabbit (1:1,000 dilution, A0216, Beyotime Ltd., China) antibody diluted in secondary antibody dilution buffer (P0023D, Beyotime Ltd., China) for $1 \mathrm{~h}$. After the membranes were washed 3 times in Tris-buffered saline with Tween for 30 min, immune complexes were visualized using an eECL Western Blot Kit (CW0049A, CWBIO Ltd., China) according to the 
manufacturer's instructions. To determine expression ratio of TMPRSS6, western blot was analyzed using Image J 1.44 software (NIH, USA).

\section{Statistical analysis}

210 Correlation coefficient between the altitudes and frequencies of CGTG deletion were

211 calculated using the $F$ test in SAS software (ver. 9.0). Candidate gene association of performed only within the same population or the population at the same elevation. used to analyze the association based on the following linear model: $Y_{\mathrm{ijk}}=\mu+G_{i}+S_{k}$

$216+\mathrm{A}_{\mathrm{j}}+\mathrm{e}_{\mathrm{ijkl}}$. Where, $\mathrm{Y}_{\mathrm{ijkl}}$ was the phenotypic value of the target trait, $\mu$ was the population mean, $\mathrm{G}_{\mathrm{i}}$ was the effect of the $\mathrm{i}^{\text {th }}$ genotype, $\mathrm{S}_{\mathrm{k}}$ was the effect of $\mathrm{k}^{\text {th }}$ gender, $A_{j}$ was the effect of the $j^{\text {th }}$ age, and $e_{i j k l}$ was the random residual [60].

\section{Results}

\section{Complete sequence of TMPRSS6 and discovery of a selected CGTG indel}

To reveal the detailed pattern of sequence variations of TMPRSS6 in pigs, resequencing of the entire genomic region of TMPRSS6 (about $40.1 \mathrm{~kb}$ ) was conducted firstly covering 30.1-kb exon-intron region, 7.4-kb 5'-region and 0.6-kb boars across continuous altitudes along the ancient Tea-horse road. A total of 708 
in high altitude above $3000 \mathrm{~m}$ displayed higher LD compared with the other pigs. And the LD increased with elevated altitudes, suggesting that altitude selection on TMPRSS6 has been consistent in both domestic pigs and wild boars. Specifically, an CGTG indel occurred in the intron 10 of TMPRSS6 gene, closely linked with SNP13, SNP15 and SNP16. The CGTG acted as the conserved core sequence of hypoxia-response elements (HREs) [61] which bound to many oxygen-regulated genes by hypoxia induced factors (HIFs) . Therefore, extensive samples were needed to determine the intron 10 sequence of TMPRSS6 gene to further reveal whether the CGTG indel played a potential role in high-altitude adaptation of Tibetan pigs.

Fig 2. Pairwise $r^{2}$ linkage disequilibrium spanning entire TMPRSS6 gene in pig breeds along

continuous altitudes. A total of 708 SNPs of nearly whole TMPRSS6 gene from 40 domestic boars; (C), MA domestic pigs; (D) MA wild boars; (E) LHA domestic pigs; (F) LHA wild boars;

(G) MHA domestic pigs; (H) MHA wild boars.

\section{Positive selection analysis of intron 10 in TMPRSS6 gene}

To test whether the observed CGTG indel was a hypoxia-selected site, the intron 10 of TMPRSS6 gene was sequenced in a total of 838 domestic pigs from 5 altitudes along the Tea-horse ancient road (Table S1 and Fig 1). As a result, 16 SNPs and the CGTG indel were screened. Genotype frequency and allele frequency were listed in 

and altitude was analyzed and a strong positive correlation $(\mathrm{r}=0.959, \mathrm{P}=0.005)$ in deletion might play a key role in contributing to high-altitude hypoxia adaptation in Tibetan pigs. Pairwise $\mathrm{r}^{2}$ linkage disequilibrium for the 16 SNPs were separately analyzed in pig breeds across continuous altitudes, and elevated $r^{2}$ values among the CGTG indel and its three neighboring sites (SNP13, SNP15, SNP16) with increased altitudes (Fig 5) suggested a genetic hitchhiking effect in domestic pigs across continuous altitudes.

Fig 3. The correlation between CGTG deletion frequency and altitude in domestic pigs. Plot of the correlation analysis between frequencies of the CGTG deletion and the altitudes among domestic pigs, " $r$ " represents the correlation coefficient $(r=0.959, \mathrm{P}=0.005)$.

Fig 4. Altitudinal pattern of allele frequency variation at the CGTG indel in pig breeds across continuous altitudes. In the pie diagram, the frequency of the deletion allele was shown in red. From south to north, the sampling altitudes were HHA (3500 m), MHA (3000 m), LHA (2500 m), MA (1500 m) and LA (500 m).

Fig 5. Pairwise $r^{2}$ linkage disequilibrium spanning the intron 10 in pig breeds across continuous altitudes. A total of 16 SNPs from 838 domestic pigs were included. The SNPs with minor allele frequency smaller than $10 \%$ were removed. Darker shading indicated higher levels of LD. (A) LA domestic pigs; (B) MA domestic pigs; (C) LHA domestic pigs; (D) MHA Tibetan 


\section{Association of the CGTG indel with blood physiological parameters}

Genome-wide association study had established the association between variants in

TMPRSS6 and hemoglobin level in humans $[44,46]$. To further investigate the role of

the CGTG deletion of TMPRSS6 in blood physiological adaptation, we genotyped the

CGTG indel and measured 20 indexes of the hematologic and hemorheologic

parameters in two high-altitude Tibetan pig populations (HHA and MHA) and three

RBC and HGB value of the insertion homozygote (II) were significantly higher than

those of the deletion homozygote (DD) $(\mathrm{p}<0.01)$, which was accompanied by similar

statistically tendencies for hemorheologic parameter WLS, WMS and WHS $(p<0.05)$.

The sex- and age-adjusted HGB and RBC were $13.25 \mathrm{~g} / \mathrm{L}$ and $0.64 \times 10^{6} / \mathrm{ul}$ lower in 


\begin{tabular}{|c|c|c|c|}
\hline RBC (10\%/ul) & $7.36 \pm 0.13 \mathrm{~B}$ & $7.65 \pm 0.10 \mathrm{AB}$ & $8.00 \pm 0.21 \mathrm{~A}$ \\
\hline HGB (g/L) & $128.55 \pm 2.22 \mathrm{~B}$ & $134.16 \pm 1.8 \mathrm{AB}$ & $141.80 \pm 3.54 \mathrm{~A}$ \\
\hline HCT (\%) & $42.44 \pm 0.73 \mathrm{~B}$ & $43.88 \pm 0.60 \mathrm{AB}$ & $46.11 \pm 1.17 \mathrm{~A}$ \\
\hline $\operatorname{MCV}$ (fl) & $58.01 \pm 0.67$ & $57.61 \pm 0.55$ & $57.86 \pm 1.08$ \\
\hline MCH (pg) & $17.50 \pm 0.20$ & $17.51 \pm 0.16$ & $17.72 \pm 0.32$ \\
\hline $\operatorname{MCHC}(\mathrm{g} / \mathrm{L})$ & $302.67 \pm 1.45$ & $305.19 \pm 1.18$ & $307.18 \pm 2.32$ \\
\hline RDW (\%) & $15.40 \pm 0.17$ & $15.65 \pm 0.14$ & $15.25 \pm 0.27$ \\
\hline FB $(g / L)$ & $3.89 \pm 0.09$ & $3.97 \pm 0.07$ & $3.66 \pm 0.14$ \\
\hline PV (mpa·s) & $1.77 \pm 0.05$ & $1.78 \pm 0.04$ & $1.66 \pm 0.08$ \\
\hline WLS & $13.85 \pm 0.43$ & $14.01 \pm 0.35$ & $15.17 \pm 0.69$ \\
\hline WMS & $3.63 \pm 0.12$ & $3.61 \pm 0.10$ & $4.01 \pm 0.20$ \\
\hline WHS & $2.75 \pm 0.1$ & $2.72 \pm 0.08$ & $3.04 \pm 0.16$ \\
\hline EAI & $5.09 \pm 0.11$ & $5.20 \pm 0.09$ & $5.09 \pm 0.18$ \\
\hline EAC & $3.49 \pm 0.08$ & $3.57 \pm 0.06$ & $3.49 \pm 0.12$ \\
\hline CV (mpa·s) & $3.95 \pm 0.14$ & $3.94 \pm 0.12$ & $4.17 \pm 0.23$ \\
\hline RBCIV (mpa·s) & $0.71 \pm 0.02$ & $0.72 \pm 0.01$ & $0.67 \pm 0.03$ \\
\hline $\operatorname{LSFR}\left(10^{9} \mathrm{SI}\right)$ & $72.62 \pm 1.94$ & $74.00 \pm 1.57$ & $75.17 \pm 3.09$ \\
\hline $\operatorname{MSFR}\left(10^{9} \mathrm{SI}\right)$ & $44.53 \pm 1.37$ & $44.72 \pm 1.11$ & $46.64 \pm 2.18$ \\
\hline HSFR (10 ${ }^{9}$ SI) & $33.63 \pm 1.13$ & $33.64 \pm 0.92$ & $35.37 \pm 1.81$ \\
\hline YS (mpa) & $8.71 \pm 0.29$ & $9.01 \pm 0.24$ & $8.93 \pm 0.47$ \\
\hline
\end{tabular}

293 Note: Different lowercase letters and capital letters in the same row represent significant and 294 extreme difference at 0.05 and 0.01 levels, respectively. 


\begin{tabular}{|c|c|c|c|}
\hline & DD $(n=12)$ & DI $(n=17)$ & II $(n=15)$ \\
\hline RBC (10\%/ul) & $7.19 \pm 0.25$ & $7.49 \pm 0.20$ & $7.08 \pm 0.19$ \\
\hline HGB (g/L) & $127.07 \pm 3.65 b$ & $134.80 \pm 2.82 \mathrm{ab}$ & $136.65 \pm 2.96 \mathrm{a}$ \\
\hline НCT (\%) & $41.03 \pm 1.09 b$ & $43.58 \pm 0.84 \mathrm{a}$ & $44.60 \pm 0.88 \mathrm{a}$ \\
\hline MCV (fl) & $57.30 \pm 1.38 \mathrm{~B}$ & $60.08 \pm 1.12 \mathrm{AB}$ & $62.09 \pm 1.07 \mathrm{~A}$ \\
\hline MCH (pg) & $17.67 \pm 0.46 \mathrm{~b}$ & $18.31 \pm 0.38 \mathrm{a}$ & $19.14 \pm 0.36 \mathrm{a}$ \\
\hline $\operatorname{MCHC}(\mathrm{g} / \mathrm{L})$ & $309.20 \pm 2.75$ & $305.86 \pm 2.23$ & $308.56 \pm 2.13$ \\
\hline RDW (\%) & $16.00 \pm 0.34$ & $15.42 \pm 0.28$ & $14.92 \pm 0.27$ \\
\hline FB $(g / L)$ & $4.81 \pm 0.34$ & $5.43 \pm 0.28$ & $5.22 \pm 0.26$ \\
\hline PV (mpa·s) & $2.17 \pm 0.16$ & $2.47 \pm 0.13$ & $2.37 \pm 0.12$ \\
\hline WLS & $9.75 \pm 0.78$ & $9.12 \pm 0.64$ & $10 \pm 0.61$ \\
\hline WMS & $2.53 \pm 0.19$ & $2.38 \pm 0.15$ & $2.57 \pm 0.15$ \\
\hline WHS & $1.89 \pm 0.14$ & $1.78 \pm 0.11$ & $1.91 \pm 0.11$ \\
\hline EAI & $5.17 \pm 0.16$ & $5.06 \pm 0.13$ & $5.23 \pm 0.12$ \\
\hline EAC & $3.53 \pm 0.11$ & $3.47 \pm 0.09$ & $3.6 \pm 0.08$ \\
\hline CV (mpa's) & $3.18 \pm 0.13$ & $3.48 \pm 0.11$ & $3.57 \pm 0.10$ \\
\hline $\operatorname{RBCIV}(\mathrm{mpa} \cdot \mathrm{s})$ & $0.89 \pm 0.06$ & $0.98 \pm 0.05$ & $0.95 \pm 0.05$ \\
\hline LSFR $\left(10^{9} \mathrm{SI}\right)$ & $60.10 \pm 3.60$ & $64.87 \pm 2.92$ & $68.56 \pm 2.79$ \\
\hline $\operatorname{MSFR}\left(10^{9} \mathrm{SI}\right)$ & $36.26 \pm 1.65$ & $39.51 \pm 1.34$ & $40.87 \pm 1.28$ \\
\hline
\end{tabular}


Note: Different lowercase letters and capital letters in the same row represent significant and extreme difference at 0.05 and 0.01 levels, respectively.

\section{TMPRSS6 mRNA and protein expression}

$27.24 \pm 1.18$

$29.78 \pm 0.95$

$30.62 \pm 0.91$

YS (mpa)

$7.32 \pm 0.59$

$7.82 \pm 0.48$

$8.48 \pm 0.45$

To investigate the regulatory effect of CGTG deletion, TMPRSS6 mRNA and protein expression level in livers [62] of HHA Tibetan pigs with genotype DD and II were detected, respectively. As shown in Fig 6A, the expression level of TMPRSS6 mRNA in liver was significantly lower in DD genotype $(n=5)$ compared with that in the II genotype $(\mathrm{n}=5)$ in HHA Tibetan pigs $(\mathrm{P}<0.01)$. In addition, the matriptase-2 protein expression level was strikingly lower in DD genotype $(n=5)$ than that of the II genotype $(n=5)$ in HHA Tibetan pigs (Figs 6B and 6C). The consistent results from RT-qPCR and western blot showed that the CGTG deletion leaded to the lower expression level of mRNA and protein in TMPRSS6.

Fig 6. mRNA and protein expression levels of TMPRSS6 in the livers of HHA Tibetan pigs. (A) The mRNA level of TMPRSS6 in the livers of HHA Tibetan pigs with the DD $(\mathrm{n}=5)$ and II (n = 5) genotype was measured by RT-qPCR. Error bars represent mean $\pm \mathrm{SD}$ from five independent experiments. ${ }^{*} \mathrm{P}<0.01$. (B) and (C) Western Blot was performed to detect the expression level of matriptase-2 protein encoded by TMPRSS6 in HHA Tibetan pigs with the DD and II genotype. $\beta$-tubulin expression was used as the loading control. DD, deletion $(n=3)$; II, insertion $(\mathrm{n}=3)$. 


\section{Discussion}

317 The Tibetan pig is one of typical high altitude domestic animals. TMPRSS6 is the typical gene correlated with the high-altitude adaption of the Tibetan pigs. And the protein encoded by TMPRSS6 is Matriptase 2 that expresses in the liver and regulates the expression of the systemic iron regulatory hormone hepcidin [51]. The hepatic hormone hepcidin regulates body iron metabolism based on the two mechanisms, the "stores regulator" and the "erythroid regulator" [63-69]. Genome-wide association studies (GWAS) have found that four erythrocyte traits, including $\mathrm{Hb}$, Hct, $\mathrm{MCH}$ and MCV, were significantly associated with TMPRSS6 in human [38,44,70]. To explore the molecular mechanism of adaptation to high-altitude hypoxia in Tibetan pigs, we conducted resequencing of the nearly complete genomic region of TMPRSS6 (40.1 $\mathrm{kb}$ ) in 40 domestic pigs and 40 wild boars and identified one CGTG deletion highly prevalent in Tibetan pigs. Haplotype analysis of sequence variations in TMPRSS6 selection. The deletion of CGTG in Tibetan pigs decreased the expression levels of TMPRSS6 mRNA and protein in the liver. The association of the CGTG deletion with blood physiology dissected a blunted erythropoietic response to high-altitude hypoxia in Tibetan pigs.

To test the signal of selection and identify causal sequence variations, resequencing of the entire genomic region of candidate TMPRSS6 gene was performed in 40 
identified, in addition to one specific CGTG deletion in intron 10 highly prevalent in Tibetan pigs $(53.7 \%$ and $62.2 \%)$. Haplotype analysis of sequence variants in TMPRSS6 gene among pig populations across continuous altitudes revealed a hitchhiking effect occurring close to CGTG deletion, suggesting that TMPRSS6 has been under Darwinian positive selection. Semenza and Wang [71] had proved HIF-1, consensus DNA binding site was a nuclear factor that was induced by hypoxia and bound to the hypoxia response element (HRE) and contained CGTG as the conserved core sequence [61]. An extensive sample of 838 domestic pigs across 5 continuous altitudes were collected to detect gene frequency of the CGTG deletion. A strong linear correlation $(\mathrm{r}=0.959, \mathrm{p}=0.005)$ between the CGTG deletion frequency and altitude gradient as well as an increased LD with elevated altitude level revealed that the CGTG indel site might be potentially selected by hypoxia.

Seen from genetic effect size, the CGTG indel showed the strong association with hemoglobin levels in HHA Tibetan pigs and its genetic effect on reducing HGB was up to $13.25 \mathrm{~g} / \mathrm{L}$. This result also explained the unchanged HGB in HHA Tibetan pigs compared with the MHA Tibetan pigs because of more CGTG deletion in HHA Tibetan pigs. This finding was consistent with Tibetans with whom the major Tibetan alleles at EGLN1 and EPASI were also associated with lower hemoglobin concentrations, both of which were associated with the HIF pathway [72-75]. Notably, except for HGB, the effects of the CGTG deletion on blood physiology were slightly different between the two HHA and MHA Tibetan pigs in that RBC was a resulting parameter in the former and $\mathrm{MCV}$ in the latter. Correspondingly, on one 
hand, the decreased RBC improved blood viscosity in HHA Tibetan pigs; on the other hand, the smaller MCV improved blood flow resistant and erythrocyte deformability in MHA Tibetan pigs. At this point, the corresponding findings to Tibetans were limited to insighting into hemoglobin concentration for EPASI and EGLN1 without detection of hemorheologic parameters. In fact, it seemed to be plausible that decreased RBC and smaller MCV, possibly affected by lowered hemoglobin level, were responsible for blunted erythropoiesis and improved blood viscosity as well as erythrocyte deformability.

In order to identify the regulatory effect of CGTG indel, mRNA and protein expression levels of TMPRSS6 in HHA Tibetan pigs with DD and II genotype were determined by RT-qPCR and western-blot experiments. As expected, the CGTG deletion leaded to the lower expression level of protein and mRNA in TMPRSS6, suggesting that HIF could not bind to HRE of TMPRSS6 gene in HHA Tibetan pigs with DD genotype under high-altitude hypoxic environment. The matriptase-2, TMPRSS6 encoding protein, can be modulated by acute iron deprivation [76,77]. In rats under acute iron deprivation, matriptase-2 protein levels increased to suppress hepcidin production and increase iron level in the liver [76], suggesting a key role of matriptase-2 in the maintenance of tight systemic iron homeostasis. Furthermore, studies also demonstrated that TMPRSS6 mRNA expression was upregulated by HIF in hypoxia $[48,72,73]$. Here, the CGTG deletion of TMPRSS6 resulted in the loss of a HRE, which down-regulated TMPRSS6 expression level and consequently induced the lower HGB and the smaller MCV underlying blunted erythropoiesis and improved 
blood viscosity and erythrocyte deformability.

\section{Acknowledgments}

The authors thank staff of the animal science and veterinary bureau of Shangri-la

County for collections of Tibetan pig samples for this study.

\section{Author Contributions}

Conceived and designed the experiments: XYK, HMM, XG. Performed the experiments: XYK, JHQ, JFY, QJ, XRL, BW, DWY, SXL. Analyzed the data: XYK, XXD. Wrote the paper: XYK, XXD, SLY.

\section{References}

1. Li M, Tian S, Jin L, Zhou G, Li Y, Zhang Y, et al. Genomic analyses identify distinct patterns of selection in domesticated pigs and Tibetan wild boars. Nat Genet [Internet]. 2013;45(12):1431-8. Available from: http://www.ncbi.nlm.nih.gov/pubmed/24162736\%5Cnhttp://www.nature.com/doifinder/10.103 8/ng.2811

2. Ai H, Yang B, Li J, Xie X, Chen H, Ren J. Population history and genomic signatures for high-altitude adaptation in Tibetan pigs. BMC Genomics [Internet]. 2014;15(1):834. Available from: http://www.pubmedcentral.nih.gov/articlerender.fcgi?artid=4197311\&tool=pmcentrez\&rendert ype $=$ abstract

3. Dong K zhe, Kang Y, Yao N, Shu G tao, Zuo Q qing, Zhao Q jun, et al. Genetic Variation of EPAS1 Gene in Tibetan Pigs and Three Low-Altitude Pig Breeds in China. J Integr Agric. 
403

404

2014;13(9):1990-8.

4. Sakai A, Matsumoto T, Saitoh M, Matsuzaki T, Koizumi T, Ishizaki T, et al. Cardiopulmonary Hemodynamics of Blue-Sheep, Pseudois nayaur, as High-Altitude Adapted Mammals. Jpn J Physiol [Internet]. 2003;53(5):377-84. Available from: http://joi.jlc.jst.go.jp/JST.JSTAGE/jjphysiol/53.377?from=CrossRef

5. Reeves JT, Leon-Velarde F. Chronic mountain sickness: recent studies of the relationship between hemoglobin concentration and oxygen transport. High Alt Med Biol. 2004;5(2):147.

6. Chen Y, Jiang C, Luo Y, Liu F, Gao Y. An EPAS1 Haplotype Is Associated With High Altitude Polycythemia in Male Han Chinese at the Qinghai-Tibetan Plateau. Wilderness Environ Med [Internet]. 2015;25(4):392-400. Available from: http://dx.doi.org/10.1016/j.wem.2014.06.003

7. Beall CM. Two routes to functional adaptation: Tibetan and Andean high-altitude natives. Proc Natl Acad Sci U S A. 2007;104(S1):8655-60.

8. Wu T, Wang XX, Wei C, Cheng H, Wang XX, Li Y, et al. Hemoglobin levels in Qinghai-Tibet: different effects of gender for Tibetans vs. Han. J Appl Physiol [Internet]. 2005;98(2):598-604. Available from: http://www.ncbi.nlm.nih.gov/pubmed/15258131

9. Wang W, Liu F, Zhang Z, Zhang Y, Fan X, Liu R, et al. The Growth Pattern of Tibetan Infants at High Altitudes: a Cohort Study in Rural Tibet region. Sci Rep [Internet]. 2016;6(6):34506. Available from: http://dx.doi.org/10.1038/srep34506

10. Qiu Q, Zhang G, Ma T, Qian W, Wang J, Ye Z, et al. The yak genome and adaptation to life at high altitude. Nat Genet [Internet]. 2012;44(8):946-9. Available from: http://dx.doi.org/10.1038/ng.2343\%5Cnpapers2://publication/doi/10.1038/ng.2343 
11. Wu X yun, Ding X zhi, Chu M, Guo X, Bao P jia, Liang C nian, et al. Novel SNP of EPAS1 gene associated with higher hemoglobin concentration revealed the hypoxia adaptation of yak (Bos grunniens). J Integr Agric [Internet]. 2015;14(4):741-8. Available from: http://dx.doi.org/10.1016/S2095-3119(14)60854-6

12. Sun J, Zhong H, Chen SY, Yao YG, Liu YP. Association between MT-CO3 haplotypes and high-altitude adaptation in Tibetan chicken. Gene. 2013;529(1):131-7.

13. Ge R-L, Cai Q, Shen Y-Y, San A, Ma L, Zhang YY-PY, et al. Draft genome sequence of the Tibetan antelope. Nat Commun [Internet]. 2013;4(May):1858. Available from: http://dx.doi.org/10.1038/ncomms2860

14. Ge RL, Kubo K, Kobayashi T, Sekiguchi M, Honda T. Blunted hypoxic pulmonary vasoconstrictive response in the rodent Ochotona curzoniae (pika) at high altitude. Am J Physiol. 1998;274:H1792-9.

15. Dong K, Yao N, Pu Y, He X, Zhao Q, Luan Y, et al. Genomic scan reveals loci under altitude adaptation in Tibetan and Dahe pigs. PLoS One. 2014;9(10):1-11.

16. Storz JF, Sabatino SJ, Hoffmann FG, Gering EJ, Moriyama H, Ferrand N, et al. The molecular basis of high-altitude adaptaion in deer mice. Plos Genet. 2007;3(3):e45.

17. Basang Z, Wang B, Li L, Yang L, Liu L, Cui C, et al. HIF2A variants were associated with different levels of high-altitude hypoxia among native tibetans. PLoS One. 2015;10(9):1-13.

18. Bigham AW, Mao X, Mei R, Brutsaert T, Wilson MJ, Julian CG, et al. Identifying positive selection candidate loci for high-altitude adaptation in Andean populations. Hum Genomics [Internet]. 2009;4(2):79-90. Available from: http://www.humgenomics.com/content/4/2/79\%5Cnhttp://www.ncbi.nlm.nih.gov/pubmed/200 
19. Gou X, Wang Z, Li N, Qiu F, Xu Z, Yan D, et al. Whole-genome sequencing of six dog breeds from continuous altitudes reveals adaptation to high-altitude hypoxia. Genome Res.

20. Simonson TS, Huff CD, Witherspoon DJ, Prchal JT, Jorde LB. Adaptive genetic changes related to haemoglobin concentration in native high-altitude Tibetans. Exp Physiol [Internet].

21. Simonson TS, Wagner PD. Oxygen transport adaptations to exercise in native highland 

http://www.pnas.org/cgi/doi/10.1073/pnas.1002443107

26. Rankin EB, Biju MP, Liu Q, Unger TL, Rha J, Johnson RS, et al. Hypoxia-inducible factor-2 (HIF-2) regulates hepatic erythropoietin in vivo. J Clin Invest. 2007;117(4):1068-77.

27. Melanie J. Percy, , Yu Jin Chung, , Claire Harrison, , Jane Mercieca, , A. Victor Hoffbrand, , Paulo C.J.L. Santos, , et al. Two new mutations in the HIF2A gene associated with erythrocytosis. Vol. 87, American Journal of Hematology. 2012. p. 439-41.

28. Nie N, Shi J, Shao Y, Li X, Ge M, Huang J, et al. A novel tri-allelic mutation of TMPRSS6 in iron-refractory iron deficiency anaemia with response to glucocorticoid. Br J Haematol. 2014;166(2):292-308.

29. Gichohi-Wainaina, W. N. Melse-Boonstra, A. Swinkels, D. W. Zimmermann, M. B. Feskens, E. J. Towers GW, Wanjiku N Gichohi-Wainaina, AlidaMelse-Boonstra, Dorine WSwinkels, Michael B Zimmermann, Edith J Feskens and GWT, Gichohi-Wainaina, W. N. Melse-Boonstra, A. Swinkels, D. W. Zimmermann, M. B. Feskens, E. J. Towers GW. Common variants and haplotypes in the TF, TNF- alpha, and TMPRSS6 genes are associated with iron status in a female black South. J Nutr 2015. 2015;145(5):945-53.

30. Guillem F, Lawson S, Kannengiesser C, Westerman M, Beaumont C, Grandchamp B. Two nonsense mutations in the TMPRSS6 gene in a patient with microcytic anemia and iron deficiency. Blood. 2008;112(5):2089-91.

31. Frýdlová J, Pøikryl P, Truksa J, Falke LL, Du X, Gurieva I, et al. Effect of Erythropoietin, Iron Deficiency and Iron Overload on Liver Matriptase-2 (TMPRSS6) Protein Content in Mice and Rats. PLoS One. 2016;11(2):1-18. 
491

32. Yaisha HM, Farrell CP, Robert D. Christensen BCM, Jackson LK, Trochez-Enciso J, Kaplan J, et al. Two novel mutations in TMPRSS6 associated with iron-refractory iron deficiency anemia in a mother and child. Blood Cells Mol Dis. 2017;65:38-40.

33. E. Beutler, C. Van Geet, D.M.W.M. te Loo, T. Gelbart, K. Crain, J Truksa and P. L, Geet C Van, Loo DMWM te, Gelbart T, Crain K, Truksa J, et al. Polymorphisms and Mutations of Human TMPRSS6 in Iron Deficiency Anemia. Blood Cells Mol Dis. 2011;44(1):1-15.

34. Gichohi-Wainaina, W. N. Melse-Boonstra, A. Swinkels, D. W. Zimmermann, M. B. Feskens, E. J. Towers GW. Common Variants and Haplotypes in the TF, TNF-a, and TMPRSS6 Genes Are Associated with Iron Status in a Female Black South African Population. J Nutr 2015. 2015;145(5):945-53.

35. Wang CY, Meynard D, Lin HY. The role of TMPRSS6/matriptase-2 in iron regulation and anemia. Front Pharmacol. 2014;5 MAY(May):1-6.

36. Xiong Y, Wu Z, Yang W, Zhao X, Peng G, Tang K, et al. A novel splicing mutation of TMPRSS6 in a Chinese child with iron-refractory iron deficiency anaemia. Br J Haematol. 2015;171(4):647-9.

37. De Falco L, Totaro F, Nai A, Pagani A, Girelli D, Silvestri L, et al. Novel TMPRSS6 mutations associated with Iron-refractory Iron Deficiency Anemia (IRIDA). Hum Mutat. 2010;31(5).

38. Benyamin B, Ferreira MARR, Willemsen G, Gordon S, Middelberg RPSS, McEvoy BP, et al. Common variants in TMPRSS6 are associated with iron status and erythrocyte volume. Nat Genet [Internet]. 2009;41(11):1173-5. Available from: http://www.nature.com/doifinder/10.1038/ng.456 

on serum hepcidin concentrations. J Med Genet [Internet]. 2011;48(9):629-34. Available from: http://www.ncbi.nlm.nih.gov/pubmed/21785125

40. Schmidt PJ, Liu K, Visner G, Fitzgerald K, Fishman S, Racie T, et al. RNAi-mediated reduction of hepatic Tmprss6 diminishes anemia and secondary iron overload in a

41. Sal E, Keskin EY, Yenicesu I, Bruno M, De Falco L. Iron-refractory iron deficiency anemia (IRIDA) cases with 2 novel TMPRSS6 mutations. Pediatr Hematol Oncol [Internet]. 2016;33(3):226-32. Available from: http://www.tandfonline.com/doi/full/10.3109/08880018.2016.1157229

42. Kodama K, Noguchi A, Adachi H, Hebiguchi M, Yano M, Takahashi T. Novel mutation in the TMPRSS6 gene with iron-refractory iron deficiency anemia. Pediatr Int. 2014;56(4):e41-4.

43. Capra AP, Ferro E, Cannavò L, La Rosa MA, Zirilli G. A child with severe iron-deficiency anemia and a complex TMPRSS6 genotype. Hematology. 2017;22(9):559-64.

44. Chambers JC, Zhang W, Li Y, Sehmi J, Wass MN, Zabaneh D, et al. Genome-wide association study identifies variants in TMPRSS6 associated with hemoglobin levels. Nat Genet [Internet]. 2009;41(11):1170-2. Available from: http://www.nature.com/doifinder/10.1038/ng.462 association analysis of serum iron concentrations. Blood [Internet]. 2010;115(1):94-6. Available from: http://www.ncbi.nlm.nih.gov/pubmed/19880490\%5Cnhttp://www.pubmedcentral.nih.gov/articl 
erender.fcgi?artid=PMC2803694

46. Soranzo N, Spector TD, Mangino M, Kühnel B, Rendon A, Teumer A, et al. A genome-wide meta-analysis identifies 22 loci associated with eight hematological parameters in the HaemGen consortium. Nat Genet [Internet]. 2009;41(11):1182-90. Available from: http://www.ncbi.nlm.nih.gov/pubmed/19820697\%5Cnhttp:/www.pubmedcentral.nih.gov/articl erender.fcgi?artid=PMC3108459

47. Du X, She E, Gelbart T, Truksa J, Lee P, Xia Y, et al. Required to Sense Iron Deficiency.

Science (80- ) [Internet]. 2008;1088(May):1088-92. Available from:

48. Meynard D, Sun CC, Wu Q, Chen W, Chen S, Nelson CN, et al. Inflammation regulates TMPRSS6 expression via STAT5. PLoS One. 2013;8(12).

49. Rausa M, Ghitti M, Pagani A, Nai A, Campanella A, Musco G, et al. Identification of TMPRSS6 cleavage sites of hemojuvelin. J Cell Mol Med. 2015;19(4):879-88.

51. Finberg KE, Heeney MM, Campagna DR, Aydınok Y. Mutations in TMPRSS6 cause iron-refractory iron deficiency anemia (IRIDA). Nat Genet. 2008;40(5):569-71.

52. Nie N, Shi J, Shao Y, Li X, Ge M, Huang J, et al. A novel tri-allelic mutation of TMPRSS6 in iron-refractory iron deficiency anaemia with response to glucocorticoid. Vol. 166, British Journal of Haematology. 2014. p. 300-3. 
53. E. Beutler, C. Van Geet, D.M.W.M. te Loo, T. Gelbart, K. Crain, J Truksa and P. L, Beutler E, Van Geet C, te Loo DMWM, Gelbart T, Crain K, et al. Polymorphisms and Mutations of Human TMPRSS6 in Iron Deficiency Anemia. Blood Cells, Mol Dis. 2010;44(1):16-21.

54. C. C. Constantine, Anderson GJ, C. D. Vulpe, C. E. McLaren, M. Bahlo, H. L. Yeap. A novel association between a SNP in CYBRD1 and serum ferritin levels in a cohort study of HFE Hereditary Haemochromatosis. Br J Haematol [Internet]. 2010 Jan 15;44(1):1-18. Available from: http://linkinghub.elsevier.com/retrieve/pii/S1079979609001685

55. Du X, She E, Gelbart T, Truksa J, Lee P, Xia Y, et al. The Serine Protease TMPRSS6 Is Required to Sense Iron Deficiency. Science (80- ) [Internet]. 2008;320(5879):1088-92. Available from: http://www.ncbi.nlm.nih.gov/pubmed/18451267\%5Cnhttp://www.pubmedcentral.nih.gov/articl erender.fcgi?artid=PMC2430097

56. Danquah I, Gahutu JB, Zeile I, Musemakweri A, Mockenhaupt FP. Anaemia, iron deficiency and a common polymorphism of iron-regulation, TMPRSS6 rs855791, in rwandan children. Trop Med Int Heal. 2014;19(1):117-22.

57. Kumar S, Stecher G, Tamura K. MEGA7: Molecular Evolutionary Genetics Analysis Version 7.0 for Bigger Datasets. Mol Biol Evol. 2016;33(7):1870-4.

58. Barrett JC, Fry B, Maller J, Daly MJ. Haploview: Analysis and visualization of LD and haplotype maps. Bioinformatics. 2005;21(2):263-5.

59. Zhang B, Qiangba Y, Shang P, Lu Y, Yang Y, Wang Z, et al. Gene expression of vascular endothelial growth factor A and hypoxic adaptation in Tibetan pig. J Anim Sci Biotechnol [Internet]. 2016;7:21. Available from: 
60. Tao C, Wang W, Zhou P, Xia T, Zhou X, Zeng C, et al. Molecular characterization, expression profiles, and association analysis with hematologic parameters of the porcine HPSE Molecular 2016):71-8.

61. Camenisch G, Stroka D, Gassmann M, Wenger R. Attenuation of HIF-1 DNA-binding activity $2001 ; 443(2): 240-9$.

62. Velasco G, Cal S, Quesada V, Sánchez LM, López-Otín C. Matriptase-2, a membrane-bound mosaic serine proteinase predominantly expressed in human liver and showing degrading activity against extracellular matrix proteins. J Biol Chem. 2002;277(40):37637-46.

63. Swenson ER, Bärtsch P. High-Altitude Pulmonary Edema. Compr Physiol [Internet]. 2012;2(October):2753-73. Available from: http://doi.wiley.com/10.1002/cphy.c100029

64. Liu C, Zhang LF, Song ML, Bao HG, Zhao CJ, Li N. Highly efficient dissociation of oxygen from hemoglobin in Tibetan chicken embryos compared with lowland chicken embryos incubated in hypoxia. Poult Sci [Internet]. 2009;88(12):2689-94. Available from: http://www.ncbi.nlm.nih.gov/pubmed/19903969

65. Cheviron ZA, Brumfield RT. Genomic insights into adaptation to high-altitude environments [Internet]. Vol. 108, Heredity. Nature Publishing Group; 2012. p. 354-61. Available from: http://dx.doi.org/10.1038/hdy.2011.85

Xia M, Chao Y, Jia J, Li C, Kong Q, Zhao Y, et al. Changes of hemoglobin expression in 
601

602

603

604

605

606

607

608

609

610

response to hypoxia in a Tibetan schizothoracine fish, Schizopygopsis pylzovi. J Comp Physiol

B Biochem Syst Environ Physiol [Internet]. 2016;186(8):1033-43. Available from:

http://link.springer.com/10.1007/s00360-016-1013-1

67. Wuren T, Simonson TS, Wei G, Wagner HE, Wuren T, Qin G, et al. Low hemoglobin concentration in Tibetan males is associated with greater high-altitude exercise capacity. $\mathrm{J}$ Physiol [Internet]. 2015;14(October 2015):1-27. Available from:

http://www.ncbi.nlm.nih.gov/pubmed/25988759

68. Liu GH, Zhou DH, Cong W, Zhang XX, Shi XC, Danba C, et al. First report of seroprevalence of swine influenza a virus in Tibetan pigs in Tibet, China. Trop Anim Health Prod.

2014;46(1):257-9.

69. Pichler I, Minelli C, Sanna S, Tanaka T, Schwienbacher C, Naitza S, et al. Identification of a common variant in the TFR2 gene implicated in the physiological regulation of serum iron levels. Hum Mol Genet. 2011;20(6):1232-40.

70. Ganesh SK, Zakai NA, van Rooij FJA, Soranzo N, Smith A V, Nalls MA, et al. Multiple loci influence erythrocyte phenotypes in the CHARGE Consortium. Nat Genet [Internet]. 2009;41(11):1191-8. Available from: http://dx.doi.org/10.1038/ng.466

71. Wang GL, Semenzas GL. Characterization of Hypoxia-inducible Factor 1 and Regulation of DNA Binding Activity by Hypoxia *. J Biol Chem. 1993;268(29):21513-8.

72. Beall CM, Cavalleri GL, Deng L, Elston RC, Gao Y, Knight JJ, et al. Natural selection on EPAS1 (HIF2) associated with low hemoglobin concentration in Tibetan highlanders. Proc Natl Acad Sci [Internet]. 2010;107(25):11459-64. Available from: http://www.pnas.org/cgi/doi/10.1073/pnas.1002443107 
73. Xiang K, Ouzhuluobu, Peng Y, Yang Z, Zhang X, Cui C, et al. Identification of a Tibetan-specific mutation in the hypoxic gene EGLN1 and its contribution to high-altitude adaptation. Mol Biol Evol. 2013;30(8):1889-98.

74. Lorenzo FR, Huff C, Myllymaki M, Olenchock B, Swierczek S, Tashi T, et al. A genetic mechanism for Tibetan high-altitude adaptation. Nat Genet [Internet]. 2014;46(9):951-6. Available from: http://www.ncbi.nlm.nih.gov/pubmed/25129147

75. Peng Y, Yang Z, Zhang H, Cui C, Qi X, Luo X, et al. Genetic variations in tibetan populations and high-altitude adaptation at the Himalayas. Mol Biol Evol. 2011;28(2):1075-81.

76. Zhang AS, Anderson SA, Wang J, Yang F, DeMaster K, Ahmed R, et al. Suppression of hepatic hepcidin expression in response to acute iron deprivation is associated with an increase of matriptase-2 protein. Blood. 2011;117(5):1687-899.

77. Meynard D, Vaja V, Sun CC, Corradini E, Chen S, López-Otín C, et al. Regulation of TMPRSS6 by BMP6 and iron in human cells and mice. Blood. 2011;118(3):747-56.

78. Maurer E, Gütschow M, Stirnberg M. Matriptase-2 (TMPRSS6) is directly up-regulated by hypoxia inducible factor-1: Identification of a hypoxia-responsive element in the TMPRSS6 promoter region. Biol Chem. 2012;393(6):535-40.

79. Lakhal S, Scho J, Pugh ARMTCW, Ratcliffe PJ, Mole DR. Regulation of type II transmembrane serine proteinase TMPRSS6 by hypoxia-inducible factors: New link between hypoxia signaling and iron homeostasis. J Biol Chem. 2011;286(6):4090-7.

\section{Supporting information}

\section{S1 Table. Sample of Blood DNA extraction}


bioRxiv preprint doi: https://doi org/10.1101/380543; this version posted July 30, 2018. The copyright holder for this preprint (which was

644 S2 Table. Sample of Blood physiological index Determination

645 S3 Table. Primer pairs information for detecting SNPs in coding region and intron in this

646 study

647 S4 Table. Genotype frequency and allele frequency of the 16 SNPs in continuous altitudes

$648 \quad$ pig populations

649 S5 Table. Associations between CGTG insert/deletion and hematologic parameters in LHA

$650 \quad$ pig populations

651 S6 Table. Associations between CGTG insert/deletion and hematologic parameters in MA

652 pig populations

653

S7 Table. Associations between CGTG insert/deletion and hematologic parameters in LA

654 pig populations 


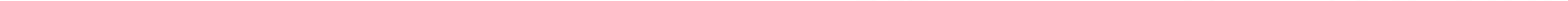


A

B

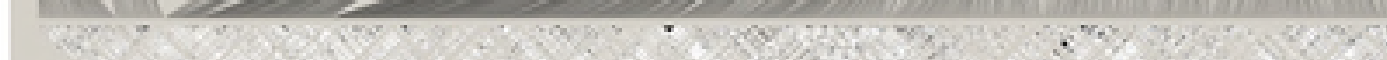

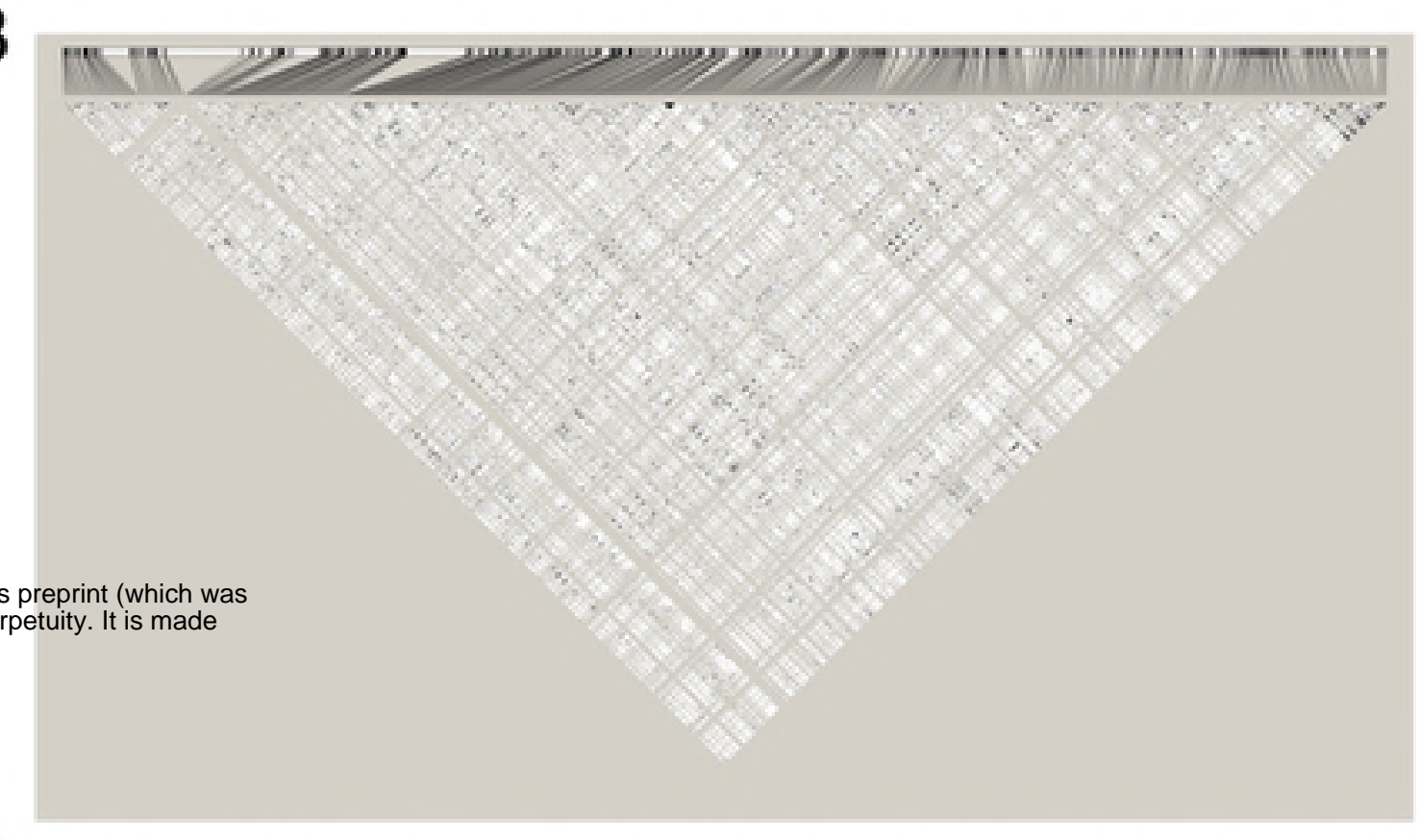
bioRxiv preprint doi: https://doi.org/10.1101/380543; this version posted July 30,2018 . The copyright holder for this preprint (which was
not certified by peer review) is the author/funder, who has granted bioRxiv a license to display the preprint in perpetuity. It is made
available under aCC-BY 4.0 International license.

C

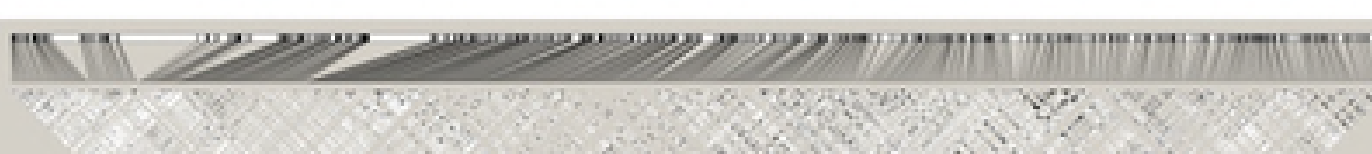

$E$

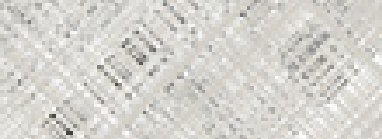

D

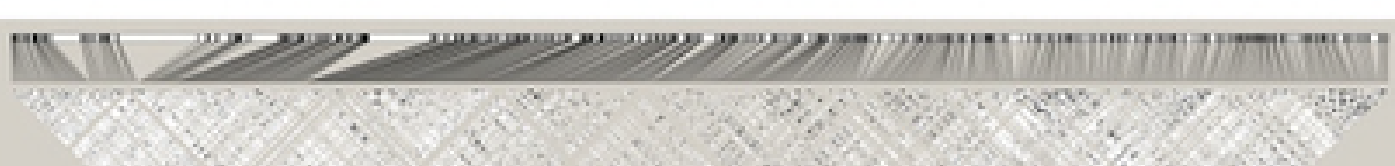

$\mathrm{F}$

\section{$\mathrm{H}$}

G

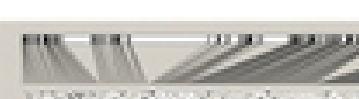




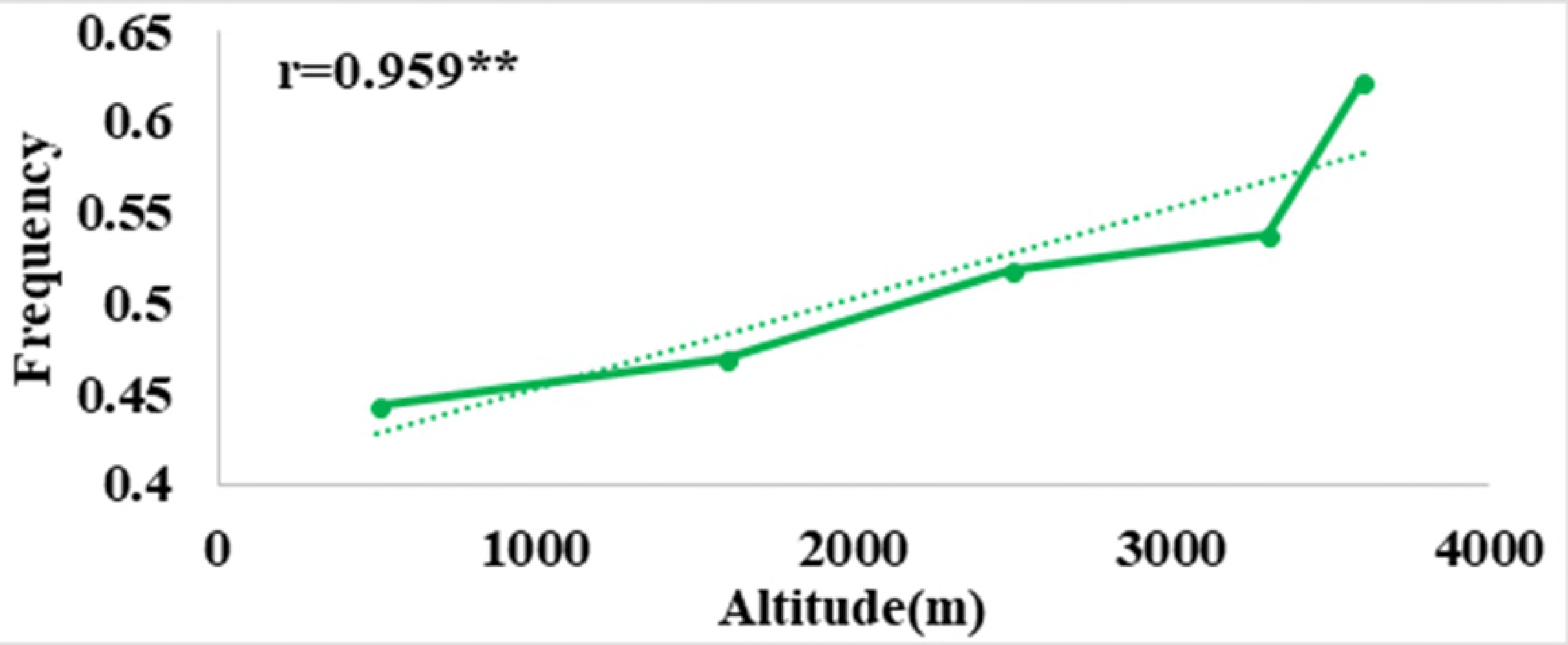




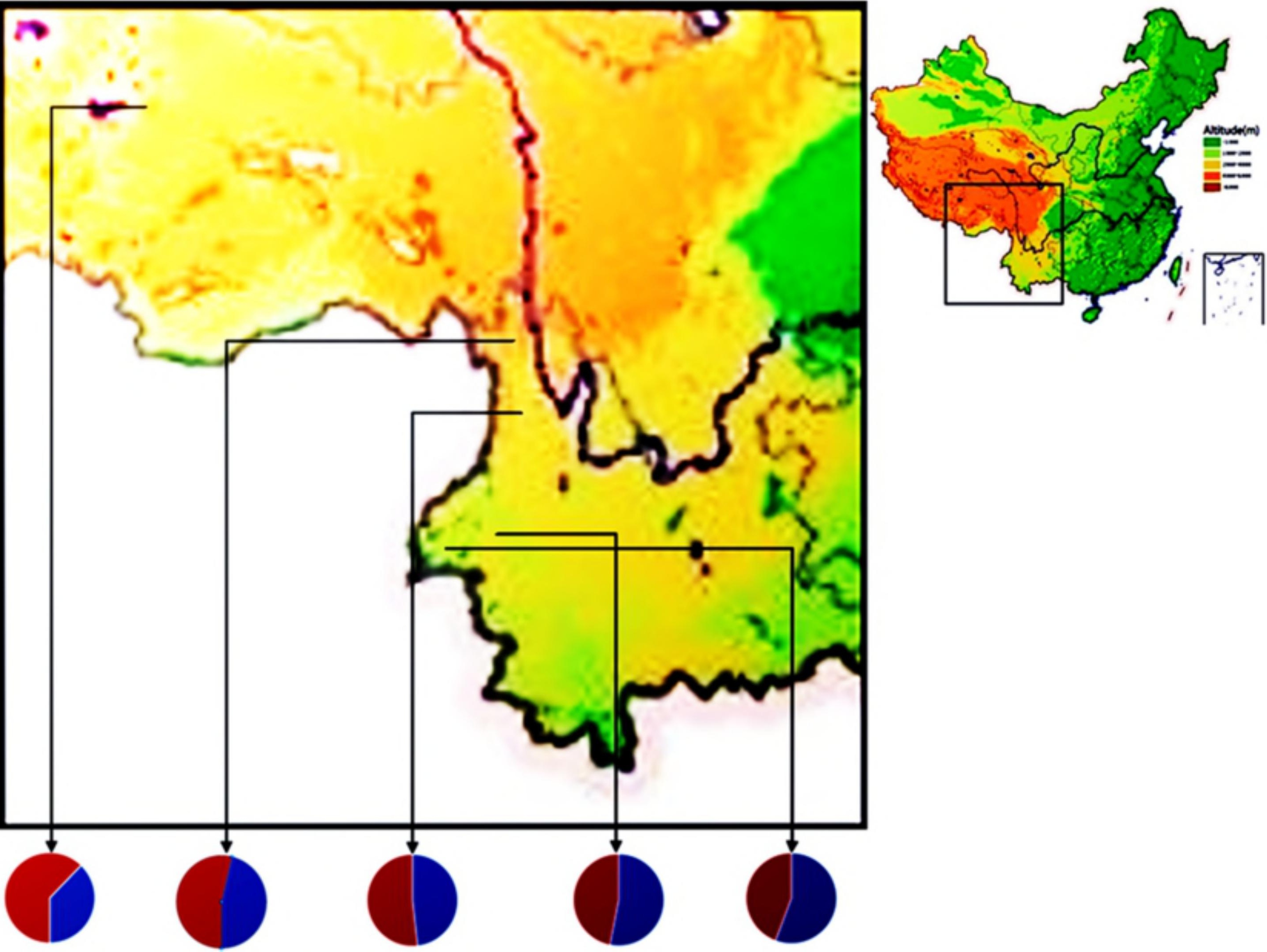




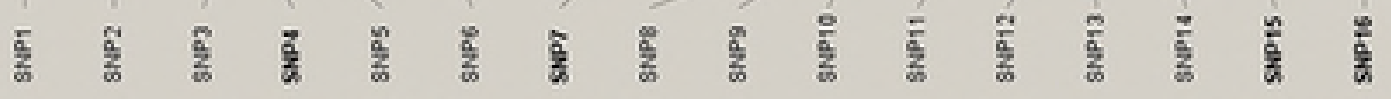

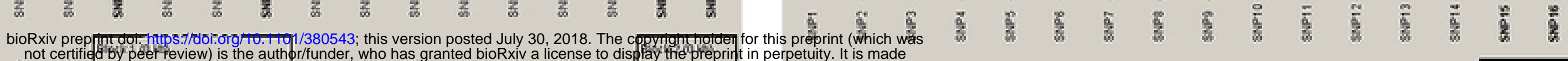
not certifiea by peef review) is the authpr/funder, who has granted bioRxiv a license to display the preprint in perpetuity. It is made

available under aCC-BY 4.0 International license.

C

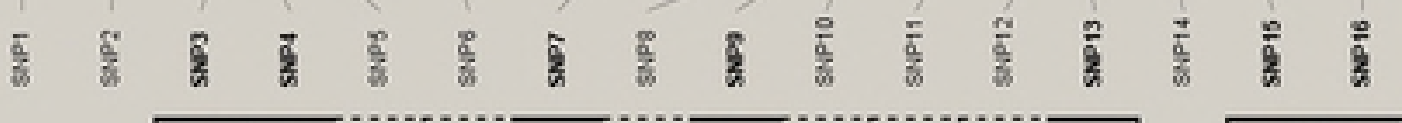
,

$\mathrm{E}$

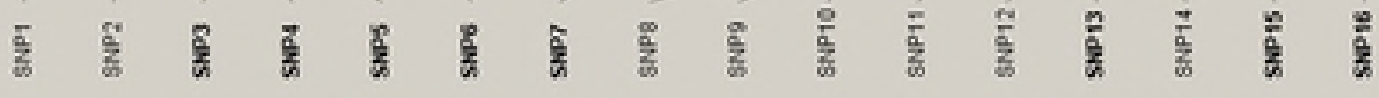

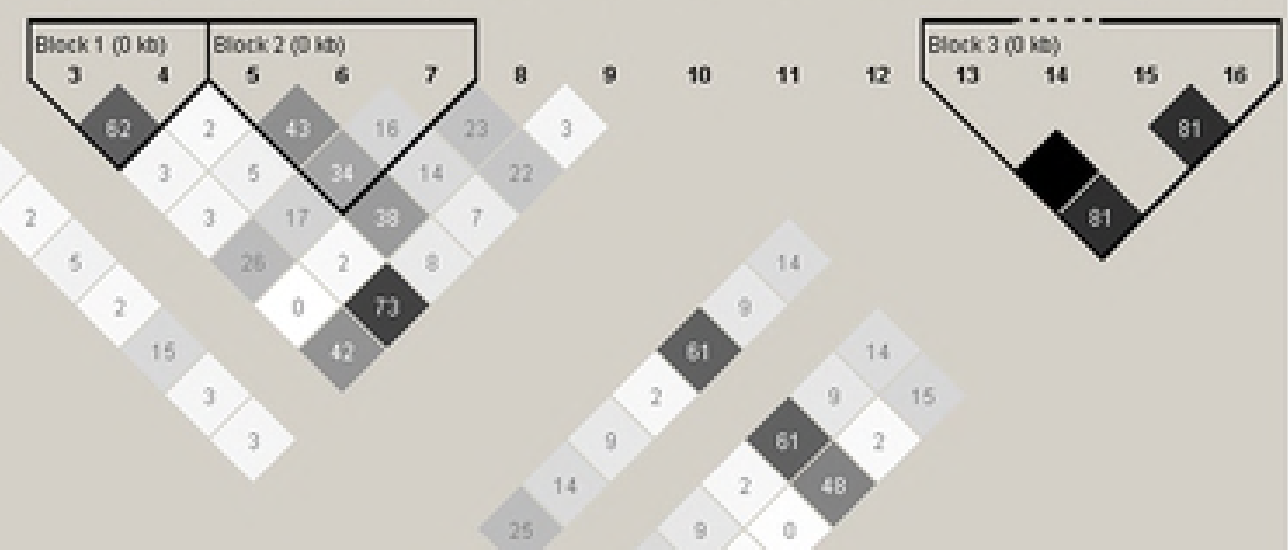

D

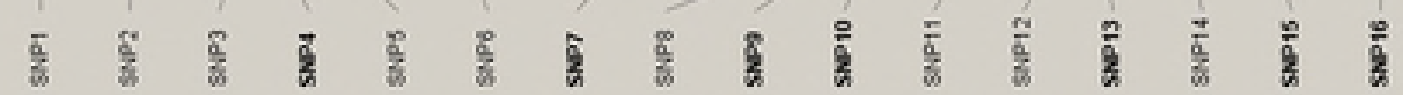

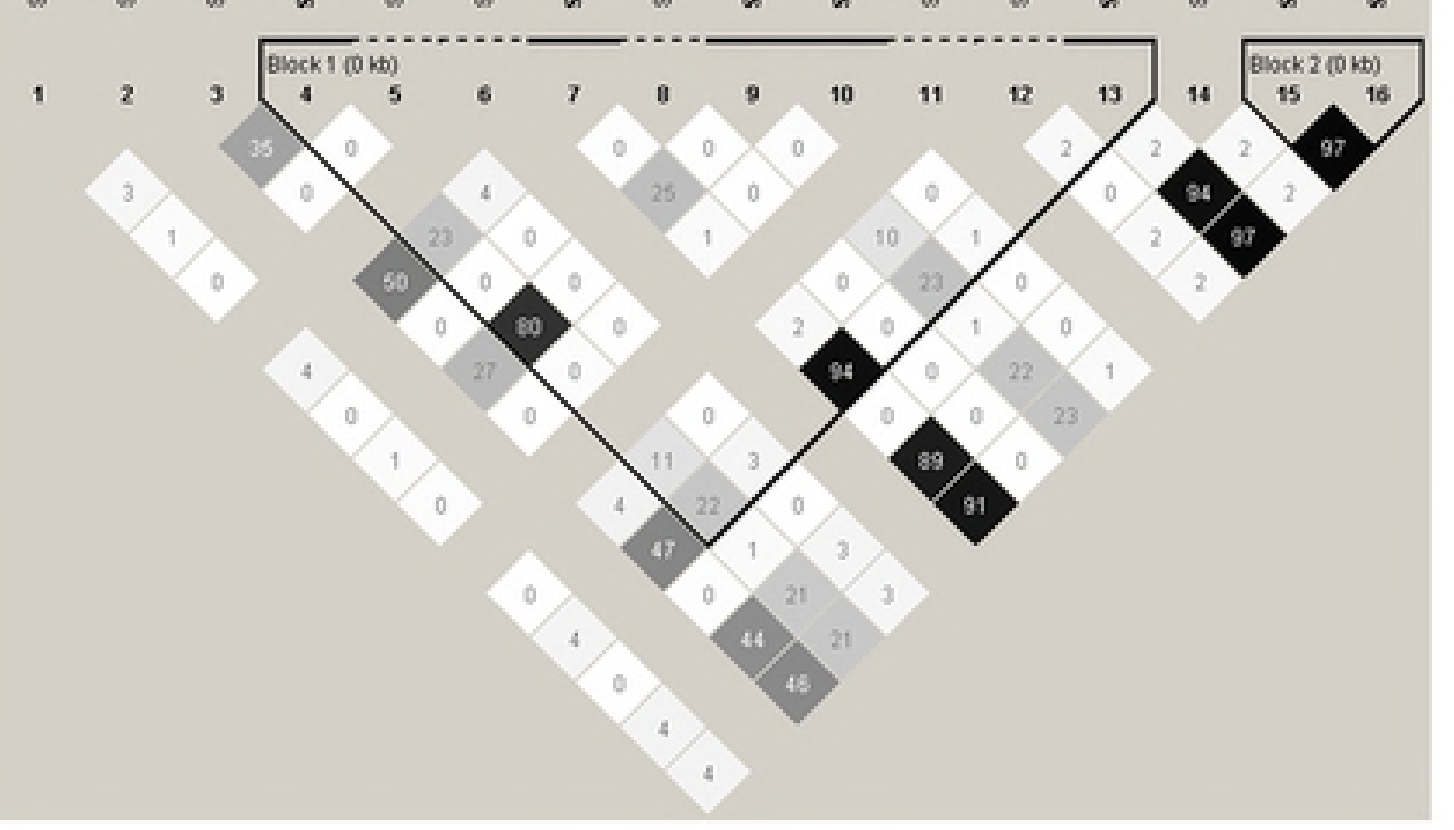


A 30.0

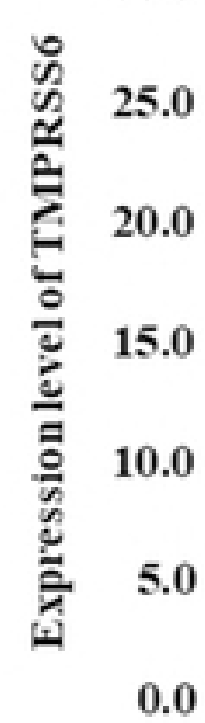

B

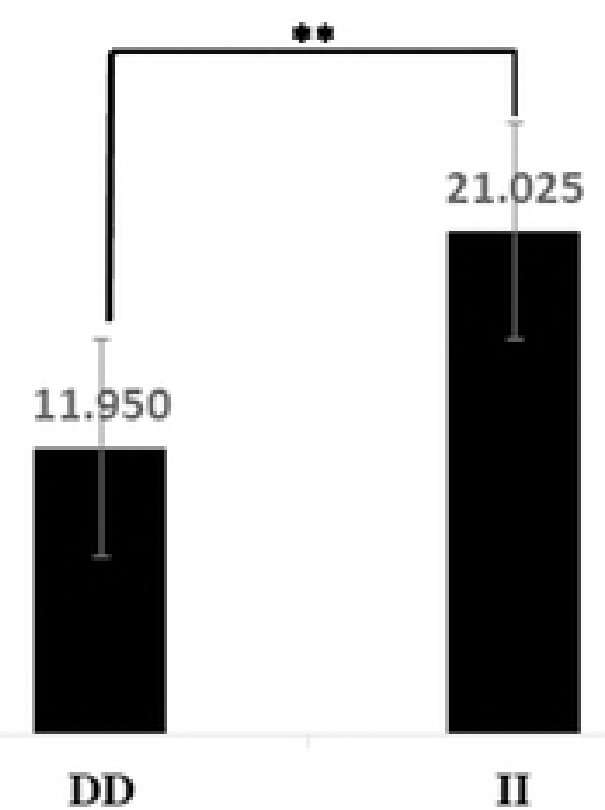

Matriptase-2

$\beta$-tubulin
C

II.

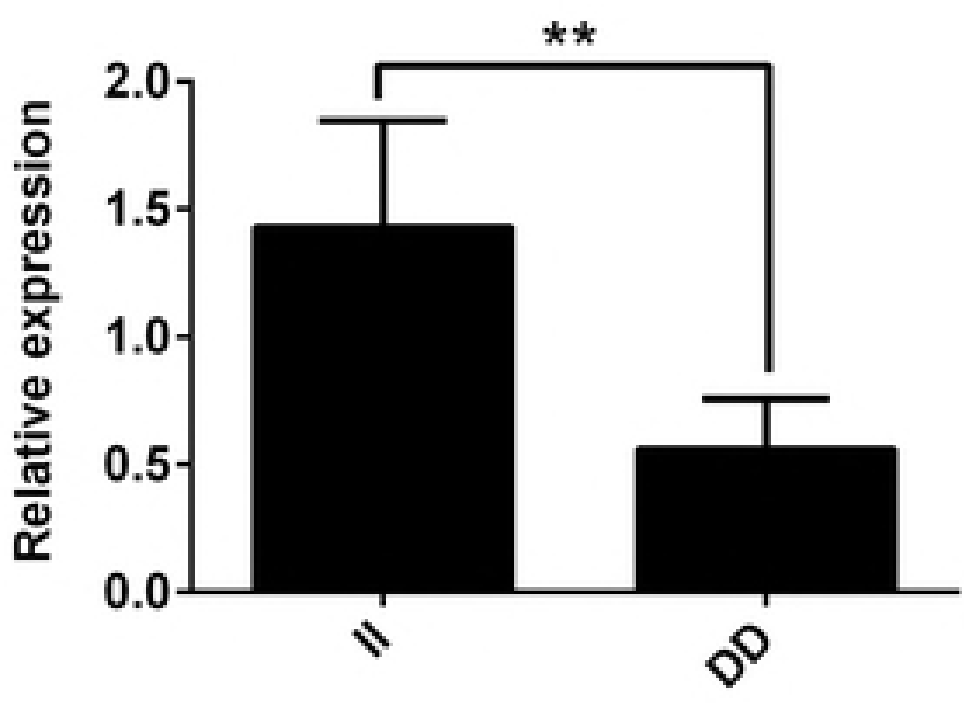

